\title{
SSB wt Allele
}

National Cancer Institute

\section{Source}

National Cancer Institute. SSB wt Allele. NCI Thesaurus. Code C142144.

Human SSB wild-type allele is located in the vicinity of 2 q31.1 and is approximately $20 \mathrm{~kb}$ in length. This allele, which encodes Lupus La protein, plays a role in metabolism of both tRNA and mRNA. 